\title{
ANALISIS PERILAKU PEMILIH PEMILIHAN KEPALA DAERAH PADA POLITIK LOKAL TAHUN 2018
}

\author{
Behavioural Voters Analysis for Regional Head Election in Local Politic in 2018
}

\author{
Cholillah Suci Pratiwi \\ Fakultas Ilmu sosial dan Politik Univesitas Jambi \\ email: cholillahsucipratiwi@yahoo.com \\ Diterima: 12 November 2019; di revisi: 25 November 2019 Disetujui : 11 Desember 2019 \\ https://doi.org/10.37250/newkiki.v3i2.40
}

\begin{abstract}
Abstrak
Perilaku pemilih erat kaitannya dengan bagaimana individu berperilaku dan berinteraksi dalam sebuah pemilihan umum, terutama terkait dengan ketertarikan dan pilihan politik mereka terhadap suatu partai politik atau kandidat yang akan dipilihnya berdasarkan etnis ataupun daerah. Penelitian ini bertujuan untuk menganalisis perilaku pemilih dalam pemilihan Kepala Daerah di Kota Jambi Tahun 2018 dengan menggunakan pendekatan kualitatif dengan metode deskriptif analisis melalui observasi, wawancara dan studi kepustakaan. Penelitian ini menjelaskan bahwa terdapat tiga model/pendekatan perilaku memilih masyarakat Kota Jambi dalam Pemilihan Kepala Daerah Tahun 2018. Pertama, model/ pendekatan sosiologis dimana perilaku memilih ditentukan oleh latar belakang sosiologis seseorang. Latar belakang sosiologis yang dimaksud antara lain adalah umur, wilayah asal seseorang (misalnya: Jawa, Luar Jawa), tempat tinggal seseorang (misalnya: kota, desa), jenis kelamin, ras dan etnis, status pekerjaan, status sosialekonomi, dan orientasi keagamaan. Kedua adalah model/pendekatan identifikasi partai yakni rasa kedekatan dengan partai politik tertentu. Serta yang terakhir adalah model/pendekatan pilihan rasional dimana perilaku memilih seseorang ditentukan berdasarkan evaluasi subjektif terhadap berbagai kondisi (ekonomipolitik-sosial) di tingkat individu maupun masyarakat.
\end{abstract}

Kata Kunci: Perilaku Pemilih, Pemilihan Kepala Daerah, Politik Lokal.

\begin{abstract}
Voter behavior is closely related to how individuals behave and interact in an election, especially related to their political interests and choices towards a political party or candidate to be chosen based on ethnicity or region. This study aims to analyze the behavior of voters in the election of Regional Heads in Jambi City in 2018 by using a qualitative approach with descriptive analysis methods through observation, interviews and literature study. This study explains that there are three models / approaches to voting behavior of the City of Jambi in the 2018 Regional Election. First, the sociological model / approach in which voting behavior is determined by one's sociological background. The sociological background in question includes among others age, area of origin of a person (for example: Java, Outside Java), place of residence of a person (for example: city, village), gender, race and ethnicity, occupational status, socio-economic status, and orientation religious. The second is the party identification model / approach, which is a sense of closeness with certain political parties. And the last is a rational choice model / approach in which one's voting behavior is determined based on subjective evaluations of various conditions (economic-political-social) at the individual or community level.
\end{abstract}

Keywords: Voter Behavior, Regional Head Election, Local Politics.

\section{Pendahuluan}

Partisipasi masyarakat dalam politik

tercermin dalam wujud pemenuhan

penggunaan hak politik. Wujud dari pemenuhan hak-hak politik adalah adanya kebebasan bagi setiap warga untuk menyatakan pendapat dan berkumpul (Surbakti 2010: 44). Seperti yang tertuang 
dalam UUD 1945 pasal 28: "kemerdekaan berserikat dan berkumpul mengeluarkan pikiran dengan lisan dan tulisan dan sebagainya ditetapkan dengan undangundang." Salah satu yang termasuk ke dalam hak politik adalah hak pilih masyarakat. Penggunaan hak pilih masyarakat tergantung pada masingmasing individu sebagai pemilih apakah akan mempergunakannya atau tidak. Penggunaan hak pilih pada pemilih dipengaruhi oleh perilaku pemilih. Perilaku pemilih merupakan perilaku mengenai alasan dan faktor yang menyebabkan seseorang memilih suatu partai atau kandidat yang ikut dalam kontestasi politik. Perilaku memilih baik sebagai konstituen maupun masyarakat umum dipahami sebagai bagian dari konsep partisipasi rakyat dalam sistem perpolitikan yang cenderung demokratis. Alamsyah (2014) juga berpendapat bahwa pelaksanaan pemilihan apapun sistem dan metodenya, keputusan akhir pada pemilih berada dua spektrum pilihan, yakni memilih atau tidak memilih. Karena pada dasarnya, pemilihan kepala daerah sejatinya dilakukan secara bebas membuat pemilih lebih independen dalam menentukan pilihan politiknya.

Dalam kontestasi politik lokal tahun 2018, Kota Jambi merupakan salah satu daerah dari total 171 daerah di Indonesia yang melakukan pemilihan kepala daerah serentak. Terdapat dua pasangan kandidat yang mengikuti kontestasi politik lokal tersebut, yaitu Drs. H. Abdullah Sani, M.Pd.I sebagai calon Walikota Jambi No Urut 1 dengan wakil Kemas Alfarizi Arsyad, S.E dan Dr. H. Syarif Fasha, M.E. serta Dr. dr. Maulana, MKM sebagai calon walikota dan wakil walikota Jambi No Urut 2 pada tahun lalu. Awalnya, Syarif Fasha bersama Abdullah Sani adalah pasangan yang bertarung dalam Pemilihan Walikota Jambi 2013 lalu. Mereka berhasil memenangi ajang pesta lima tahunan hingga resmi menjabat Wali Kota dan Wakil Wali Kota Jambi 2013-2018. Kini, pasangan kader Golkar-PDIP itu memilih pisah jalan untuk sama-sama maju sebagai bakal calon Walikota Jambi 2018-2023. Kali ini, Syarif Fasha berpasangan dengan Maulana yang merupakan seorang dokter sekaligus pemilik salah satu rumah sakit ternama di Kota Jambi. Oleh sejumlah pengamat politik maupun survei di Jambi, pasangan ini memiliki popularitas dan elektabilitas yang tinggi (www.liputan6 .com/pilkada/).

Pasangan ini juga didukung kekuatan yang lumayan, yakni 10 partai. Termasuk beberapa partai besar. Di antaranya Demokrat, Golkar, Gerindra, Hanura, PKB, 
PKS, PBB, PPP, PKPI dan Nasdem. Dengan perahu sebanyak itu, pasangan Fasha-Maulana berhasil mengantongi dukungan 30 kursi dari 45 kursi di DPRD Kota Jambi. Sementara sang lawan yakni Abdullah Sani memilih berpasangan dengan salah satu tokoh muda Kota Jambi, Kemas Al Farizi atau biasa disapa Izi. Ia juga dikenal sebagai tokoh pengusaha muda di Jambi. Tak kalah pamor, pasangan ini dianggap sebagai representasi perpaduan tokoh tua dan tokoh muda di Jambi. Sementara Abdullah Sani selain duduk sebagai Wakil Wali Kota Jambi, ia adalah tokoh PDIP yang sekaligus tokoh masyarakat dan pemuka agama di Jambi. Pasangan ini didukung dua kekuatan besar yakni PAN dan PDIP. Sama seperti pasangan Syarif Fasha-Maulana, meski hanya didukung dua partai, pasangan Abdullah Sani-Izi juga digadang-gadang bakal meraup suara besar di Pemilihan
Kepala Daerah Jambi 2018. Pamor Gubernur Jambi kala itu, Zumi Zola sebagai Ketua DPW PAN Provinsi Jambi menjadi jaminannya. Hal itu sudah terbukti pada gelaran Pemilihan Kepala Daerah serentak 2017 lalu. Meski dikepung banyak partai, kekuatan PAN di Jambi yang dikomandoi Zumi Zola berhasil mengantar Masnah Busro sebagai Bupati Muaro Jambi sekaligus satu-satunya dan pertama kalinya bupati perempuan di Provinsi Jambi (www.liputan6.com).

Namun berdasarkan hasil rekapitulasi penghitungan suara Pemilihan Kepala Daerah 2018, didapatkan bahwa sang pertana walikota berhasil mendapatkan suara terbanyak pada pemilihan kepala daerah tersebut. Hasil suara menunjukkan bahwa Fasha-Maulana unggul dibeberapa kecamatan di Kota Jambi, dengan rincian sebagai berikut:

Tabel 1. Hasil Rekapitulasi Penghitungan Suara Pada Pilkada Kota Jambi 2018

\begin{tabular}{|c|c|c|c|}
\hline \multirow{2}{*}{ No } & \multirow{2}{*}{ Kecamatan } & \multicolumn{2}{|c|}{ Jumlah Suara } \\
\cline { 2 - 4 } & & Sani-Izi & Fasha-Maulana \\
\hline 1. & Alam Barajo & 17.581 & 23.967 \\
\hline 2. & Danau Sipin & 8.086 & 12.485 \\
\hline 3. & Danau Teluk & 2.358 & 4.625 \\
\hline 4. & Jambi Selatan & 12.724 & 13.411 \\
\hline 5. & Jambi Timur & 14.721 & 16.951 \\
\hline 6. & Jelutung & 12.842 & 14.972 \\
\hline 7. & Kotabaru & 13.600 & 18.625 \\
\hline 8. & Pal Merah & 22.577 & 22.096 \\
\hline 9. & Pasar & 2.335 & 2.814 \\
\hline 10. & Pelayangan & 2.297 & 4.577 \\
\hline 11. & Telanaipura & 1.117 .435 & 13.129 \\
\hline & Total & & 2.147 .652 \\
\hline
\end{tabular}

Sumber: KPU Kota Jambi 
Berdasarkan data rekapitulasi di atas, dinyatakan bahwa identifikasi partai dan pamor ketokohan bukanlah hal utama yang memengaruhi posisi optimal perilaku memilih yang selama ini jarang digunakan oleh ilmuwan politik untuk menjelaskan karakteristik elektoral dalam politik lokal di Indonesia (Liddle dan Mujani, 2015; Mujani, et al., 2016). Akan tetapi, terdapat beberapa faktor lain yang menyebabkan seseorang menjatuhkan pilihan kepada seorang kandidat. Pemilih tidak lagi diasosiasikan dengan partai atau kelompok tertentu.

\section{Metode}

Penelitian ini menggunakan jenis penelitian deskriptif kualitatif. Fokus dari penelitian ini yaitu: analisis dari perilaku pemilih dalam pemilihan kepala daerah pada ranah politik lokal Kota Jambi Tahun 2018. Analisis ini guna melihat faktorfaktor apa saja yang kemudian mempengaruhi para pemilih untuk menentukan pilihannya. Dalam rangka mendapatkan data sesuai dengan fokus penelitian, maka peneliti melakukan kegiatan observasi, wawancara dan dokumentasi. Kemudian data yang diperoleh di lapangan bertempat di wilayah Kota Jambi, dianalisa menggunakan metode analisa interaktif, yaitu peneliti dituntut untuk melakukan kegiatan pengumpulan data, reduksi data, penyajian data, dan penarikan kesimpulan.

Berbicara tentang perilaku pemilih, perilaku pemilih itu bisa timbul dari isuisu dan kebijakan-kebijakan politik yang menjadi faktor seseorang memiliki pilihan politik yang berbeda satu sama lain. Faktor-faktor yang mempengaruhi pilihan politik ditentukan oleh faktor internal dan juga faktor eksternal.

\section{HASIL DAN PEMBAHASAN \\ Perilaku Pemilih}

Perilaku memilih (voting behavior) adalah proses penentuan keputusan seseorang untuk memilih (atau tidak memilih) partai atau kandidat tertentu dalam sebuah pemilihan umum. Menurut Evans, perilaku memilih dapat dilihat dari dua level analisis yang berbeda, yakni level mikro (individu) dan level makro (masyarakat). Studi tentang perilaku pemilih di tingkat mikro yang dilakukan secara agregat dapat menghasilkan data agregat di tingkat regional atau nasional (Evans, Jocelyn A J. 2004).

Istilah pemilihan atau pemberian suara (voting) sebenarnya sudah dikenal dalam terminologi Ilmu Politik sejak lama. Mulai dari Aristoteles sampai De Tocqueville mencantumkan istilah voting 
dalam karya-karya mereka. Namun demikian, studi tentang perilaku memilih secara lebih khusus dan fokus baru dilakukan pada awal abad ke-20. Salah satu di antaranya adalah Siegfried (1913) yang melakukan penelitian mengenai pola pemilihan (voting patterns)di Prancis bagian Barat sebelum Perang Dunia I. Woshinsky mengidentifikasi dua kelompok variabel yang diyakini memiliki pengaruh signifikan terhadap perilaku memilih. Pertama adalah variabel objektif, seperti kelas, ras, agama, etnis, gender, tempat tinggal, kedaerahan, dan usia. Kedua adalah perspektif subjektif individu pemilih terhadap dirinya sendiri (Evans, Jocelyn A J. 2004: 21). Namun demikian, Woshinsky mengakui bahwa perilaku memilih adalah sesuatu yang kompleks. “Apa yang ada dalam benak pemilih adalah gabungan antara pengalaman hidup dan pemahaman mengenai pengalaman hidup, yang menentukan di hari pemilihan (Woshinsky, Oliver H. 2008: 132).”

Dilihat berdasarkan faktor-faktor utama yang mempengaruhi pemilih, Heywood mengelompokkan perilaku pemilih ke dalam tiga model atau pendekatan, yakni: model sosiologis, model identifikasi partai dan model pilihan rasional (Heywood, Andrew. 2007: 266).

\section{Model Sosiologis}

Sosiologis dikembangkan berdasarkan penelitian di Erie County, Ohio, Amerika Serikat, pada awal tahun 1940-an. Paul Lazarsfeld dan kawankawan melakukan sedikitnya tujuh panel survei terhadap 600 responden, baik dengan pertanyaan yang sama maupun yang berbeda. Tujuan utama survei tersebut adalah untuk mengetahui bagaimana perubahan perilaku pemilih selama kampanye pemilihan presiden (Bartels, Larry M. 2009). Karena dilakukan oleh para peneliti dari Columbia University, maka model ini sering juga disebut Model Columbia. Kesimpulan utama penelitian mereka adalah bahwa perilaku memilih ditentukan latar belakang sosiologis seseorang. Latar belakang sosiologis yang dimaksud antara lain adalah umur, wilayah asal seseorang (misalnya: Jawa, Luar Jawa), tempat tinggal seseorang (misalnya: kota, desa), jenis kelamin, ras dan etnis, status pekerjaan, status sosial-ekonomi, dan orientasi keagamaan.

Model ini juga menyatakan bahwa proses kampanye dan pemberitaan media massa memiliki pengaruh yang kecil terhadap preferensi memilih seseorang, sebab pada saat kampanye dilakukan 
sebagian besar pemilih sudah memiliki keputusan mengenai kandidat atau partai yang akan mereka pilih. Publikasi awal model sosiologis dapat dilihat pada The People's Choice yang ditulis Lazarsfeld,
Berelson, Gaudet (1944); serta Voting karya Berelson, Lazarsfeld, McPhee (1954). Proses penentuan pilihan dalam Model Sosiologis digambarkan dalam Gambar 1 di bawah ini:

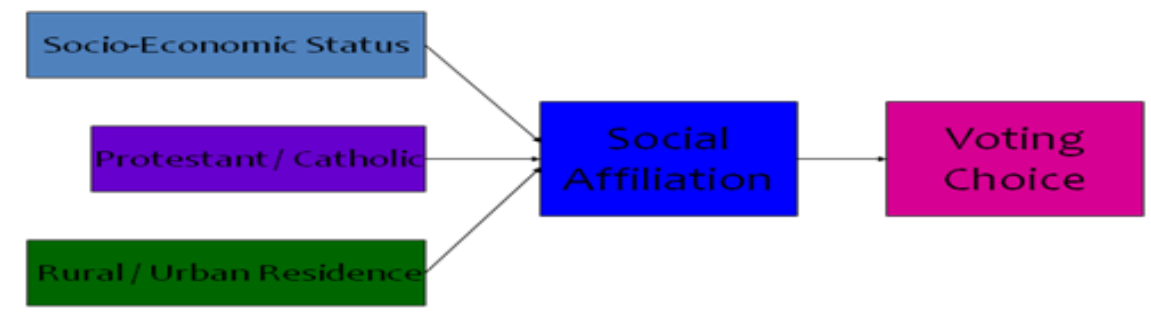

Picture 1. Columbia Sociological Model

Pada umumnya menempatkan kegiatan memilih pada kaitan dengan pendidikan, jabatan, pekerjaan, jenis kelamin, usia dan etnis. Hal ini diutarakan oleh informan saat diwawancara, Dony Maralis (44 tahun, Kepala Desa Wijaya Pura Periode 2010-2015) "Saya memilih salah satu calon karena calon tersebut adalah pimpinan saya saat itu. Jadi saya harus loyal pada atasan, selain itu dalam masa kepemimpinannya, kandidat tersebut banyak membantu saya dalam menjalankan program-program di desa." Hal demikian pula diutarakan salah satu PNS, Noni Runtukahu (49 tahun, Kepala Sekolah di SD Adhyaksa Jambi) "Saya harus loyal pada salah satu calon yang adalah pimpinan di Kota Jambi saat itu. Karena sudah memberi bantuan banyak pada guru-guru dan para murid serta sudah mengangkat saya menjadi kepala sekolah." Berdasarkan pernyataan yang dikemukakan oleh dua informan penulis, menujukkan perilaku yang memilih berdasarkan jabatan. Perilaku ini disebabkan karena takut kehilangan jabatan atau pekerjaan. Selain itu, keputusan politik yang dibuat, mampu mempengaruhi orang lain dengan alih-alih untuk mendapatkan jabatan yang tetap. Reva Aditya (17 tahun, Pelajar SMA, Pemilih Pemula) mengatakan memilih salah satu calon karena keinginan sendiri namun ada kepentingan dibalik itu. "Dalam kepemimpinan sebelumnya, ibu saya susah masuk Pegawai Negeri Sipil. Jadi saya bukan memilih incumbent, supaya lebih mudah untuk mendapat pekerjaan tetap." Pernyataan di atas menunjukkan ada peran orang tua dalam mempengaruhi pilihan anaknya. Dianggap belum bisa menentukan pilihan sendiri karena baru pertama kali 
memilih, orang tua pun mengarahkan anaknya. Menurut penulis, seharusnya ia diberi kebebasan dalam menentukan pilihannya sendiri.

Tidak hanya dalam hal jabatan, dalam usia dan etnis pun mempengaruhi seseorang untuk memilih. Hendra (35 tahun, Karyawan Swasta) dalam wawancara mengatakan, "Dalam hal usia, saya tidak pilih-pilih. Karena tetap dilihat dari kapabilitas calon pemimpin tersebut. Ada yang tua namun ternyata kepemimipinan seorang muda yang lebih baik." Dalam hal ini menujukkan mengenai usia, beliau melihat kapabilitas dari calon tersebut. Ini artinya akan ada perubahan setiap saat beliau akan menentukan pilihannya. Hal berbeda diutarakan Aldo Ticoalu (25 tahun, Pegawai Bank BRI, Intelektual), Suyadi (55 tahun) dan Barim Kasim (48 tahun). Bagi mereka untuk menjadi satu pemimpin kesamaan asal daerah atau suku menjadi hal yang penting. Menurutnya, calon pemimpin bersuku jawa memiliki jiwa pekerja keras dan memiliki integritas tinggi serta lebih memiliki kedekatan emosional dengan mereka. Kemudian lebih jelas lagi Aldo mengemukakan pandangannya dari segi pendidikan. "Intelektual menjadi faktor penentu untuk memilih. Karena pendidikan merupakan kunci utama dalam hal kepemimpinan. Bahkan saat studi kita diajarkan bagaimana cara memimpin melalui organisai-organisasi maupun lembaga-lembaga yang ada."

Dari ungkapan di atas menunjukkan adanya kesadaran dalam memilih dari segi pendidikan. Aldo juga melihat pendidikan sebagai faktor utama dalam menentukan pilihannya. Dalam proses pendekatan sosiologis akan terkait dengan pendekatan psikologis.

\section{Model Identifikasi Partai}

Model Identifikasi Kepartaian atau Model Sosial - Psikologis yang dikembangkan oleh Campbell, Converse, Miller, dan Stokes (1960) dari Michigan University. Menurut model ini, preferensi politik seseorang dalam pemilihan umum bukan hanya ditentukan oleh karakteristik sosial pemilih, tetapi juga dipengaruhi faktor-faktor psikologis. Campbell dan kawan-kawan memunculkan konsep identifikasi kepartaian (party identification atau partisanship) yakni rasa kedekatan dengan partai politik tertentu. Konsep ini menjadi rujukan banyak peneliti yang mengkaji masalah perilaku pemilih sampai hari ini.

Selang beberapa tahun setelah penelitian di Erie County, para peneliti dari Michigan University, melakukan survei secara nasional menjelang pemilihan 
presiden Amerika Serikat tahun 1948. upcoming presidential election and for Survei tersebut pada awalnya dilakukan which party - pada bagian akhir tidak secara khusus untuk mengetahui wawancara, dengan tujuan untuk perilaku pemilih, melainkan untuk mengetahui tingkat ketertarikan dan mengetahui opini masyarakat terhadap kebijakan politik luar negeri Amerika Serikat. Namun, "at the end of these interviews, in order to determine the degree of political interest of the respondents and their general political orientation, had asked respondents whether they planned to vote in the orientasi politik responden secara umum, kepada responden ditanyakan apakah mereka berencana akan memilih pada pemilu presiden yang akan datang dan memilih partai apa (Davidson, Donald, 2004: 8)." Proses penentuan suara dalam Model Identifikasi Partai digambarkan dalam Gambar 2 di bawah ini:

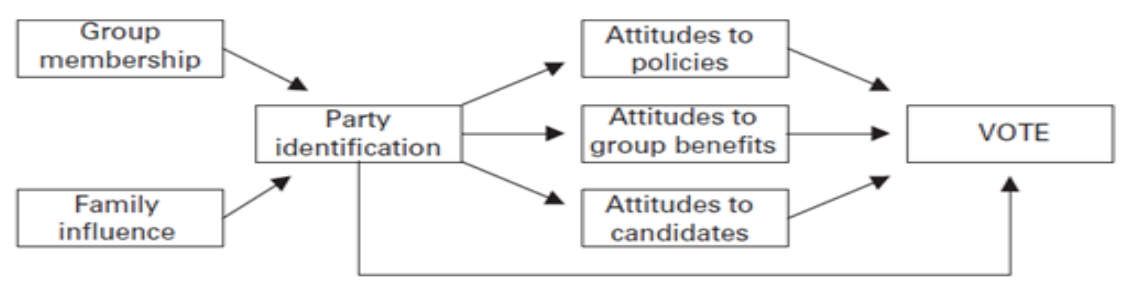

Picture 2. The Party Identifications Model

Identifikasi partai digunakan untuk mengukur sejumlah faktor pribadi maupun politik. Seperti pengalaman pribadi atau orientasi politik yang relevan bagi individu. Pengalaman pribadi dan orientasi politik sering dipengaruhi oleh situasi dan kondisi lingkungan. Sementara evaluasi terhadap kandidat melihat dilihat karena sejarah yang telah diukir atau masa lalu kandidat. Namun figur kandidat dianggap paling memiliki ketertarikan dan sosok idaman bagi masyarakat dalam penelitian ini lebih mempengaruhi psikologis pemilih. Seperti yang diungkapkan seorang informan Deisy Montung (45 tahun, tim sukses salah satu calon). "Figur dari calon kepala daerah yang paling penting. Kota Jambi butuh pemimpin seperti kandidat yang saya pilih, seperti ingin berbagi dengan tulus pada masyarakat bahkan membantu dengan siapa saja termasuk orang yang tidak dikenal.” Lebih lanjut Deisy mengatakan, "Saya menyatakan mendukung beliau saat penetapan kandidat. Dibalik itu saya juga mengenal pribadinya secara baik, jauh sebelum terjun di dunia politik.” 
Berdasarkan kutipan di atas, menunjukkan pula adanya perilaku dalam memilih berdasarkan pendekatan psikologis. Dimana sosok idolalah yang dipilih sebagai calon kepala daerah. Sebagaimana diutarakan oleh salah satu informan Daniel Sialagan (61 tahun, pensiunan PT. Jaya Abadi, tim sukses salah satu kandidat) menyatakan, "Calon yang saya pilih memiliki loyalitas dan kepedulian terhadap masyarakat meskipun ada beberapa kebijakannya yang tidak sepenuhnya pro rakyat." Pernyataan di atas jelas menggambarkan adanya evaluasi terhadap kandidat. Hal ini kemudian mempengaruhi penilain terhadap kandidat. Pemilih melihat sosok calon yang loyal dan memiliki kepedulian yang sudah dipraktekkan pada masyarakat Kota Jambi. Berbeda dengan yang diutarakan informan lain Erni (60 tahun, Mantan Guru SMP N 3 Kota Jambi, Lanjut Usia) mengatakan: "Saya memilih salah satu kandidat kepala daerah yang tergabung dalam koalisi partai pendukung yang saya sukai dan kagumi." Sepanjang sejarah partai penguasa di Kota Jambi, Partai Golkar dan PDIP selalu memiliki kedekatan kepada pemilih selaku partai besar. Kedekatan pemilih dengan partai Golkar dan PDIP sangat memengaruhi relevansi keterpilihan kandidat karena sebagian besar daerah di
Kota Jambi adalah daerah transmigrasi Orde Baru, masyarakat daerah transmigran dikenal dekat dengan Golkar dan PDIP. Bagi sebagian masyarakat transmigran, Golkar dan PDIP adalah salah satu bagian dari hidup mereka. Perilaku pemilih tersebut menunjukkan bahwa, ada ikatan emosional dari pemilih terhadap kandidat. Menurut penulis, penilaian Erni terhadap kandidat karena pengaruh kekuatan psikologis yang berkembang dalam dirinya sebagai produk dari sosialisasi yang ia terima.

\section{Model Pilihan Rasional}

Sementara itu, Model Pilihan Rasional pertama kali diperkenalkan oleh Anthony Downs dalam karyanya $A n$ Economic Theory of Democracy (1957) dan dikembangkan antara lain oleh Olson dalam The Logic of Collective Action (1965). Model pilihan rasional percaya bahwa perilaku memilih seseorang ditentukan berdasarkan evaluasi subjektif terhadap berbagai kondisi (ekonomipolitik-sosial) di tingkat individu maupun masyarakat. Biasanya berlaku prinsip penghargaan (reward) dan hukuman (punishment) terutama terhadap kandidat petahana (incumbent). Jika keadaan ekonomi dan sosial dianggap baik, maka pemilih cenderung memberikan penghargaan dengan memilih kembali 
kandidat atau partai yang berkuasa. Sebaliknya jika keadaan ekonomi dan sosial dinilai tidak baik, maka pemilih akan menghukum kandidat atau partai yang berkuasa dengan cara memberikan suaranya kepada kandidat atau partai lain.

Evaluasi subyektif pemilih tersebut dapat berlaku secara egosentrik (dari perspektif yang dialami langsung oleh pemilih) maupun secara sosiotropik (penilaian terhadap kondisi makro secara regional maupun nasional). Model pilihan rasional percaya bahwa faktor-faktor ekonomi memiliki peranan yang menentukan terhadap perilaku memilih seseorang. Karena itu model ini sering juga disebut model economic voting (Dorussen, Han 2002).
Menurut Evans, pemilih cenderung memilih partai dan calon atas dasar manfaat yang didapat atau dijanjikan (Evans, Jocelyn A J. 2004). Manfaat yang diharapkan dari pemberian suara akan bervariasi tergantung latar belakang pemilih. Namun, beberapa diantara faktor yang memotivasi pemilih dapat berupa: manfaat bagi kelompok (misalnya kebijakan tertentu bagi kelas pekerja); keuntungan materi (misalnya penurunan pajak); kompetensi manajerial (misalnya peningkatan kualitas pelayanan publik); fokus pada isu-isu yang relevan (misalnya kebijakan lingkungan untuk mengurangi polusi); dan kekalahan pihak lain (misalnya memilih partai konservatif untuk menahan partai sosialis yang tidak disuka pemilih).

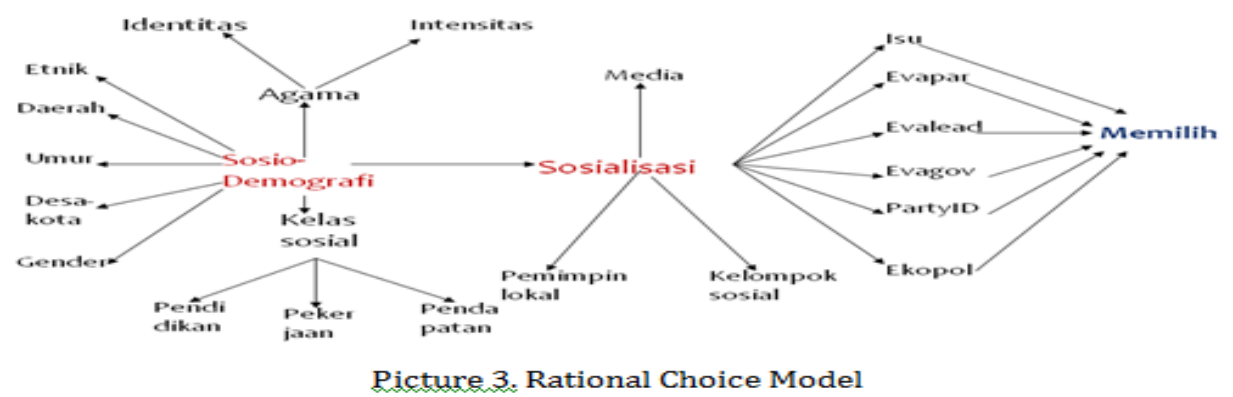

Teori Afan Gaffar mengenai sumber daya, dan karena itu pemilih perlu perilaku pemilih teori dalam pendekatan membuat pilihan. Untuk menetukan sikap teori V. O. Key. dimana pendekatan pilihan dan tindakan yang efisien pemilih harus rasional, selalu mempunyai tujuan-tujuan memilih antara beberapa alternatif dan yang mencerminkan apa yang dianggapnya kepentingan diri sendiri. Pemilih melakukan hal itu dalam situasi terbatasnya yang menentukan alternatif mana yang maksimal baginya. Ada beberapa informan yang memilih berdasarkan pilihan rasional. 
Berikut ini adalah petikan hasil wawancara dengan Ansella Korompis (35 tahun, Ibu Rumah Tangga) yang mengatakan, "Perekonomian masyarakat saat ini sangat menurun dibandingkan tahun lalu. Banyak pengangguran, kebutuhan pokok. Jujur saja, saya memilih kandidat yang memiliki finasial di atas rata-rata. Zaman sekarang ada uang ada suara." Perilaku pemilih di atas menunjukkan bahwa motivasi menjadi hal utama dalam memilih. Dimana keterbatasannya lapangan pekerjaan dan penggagguran, mendorong Ansella untuk menentukan sikap terhadap pilihannya pada Pemilihan Kepala Daerah Kota Jambi Tahun 2018.

Hal lain juga diutarakan Jemmy Kaseger (39 tahun, tukang ojek, tim sukses salah satu calon) katanya: "Salah satu kandidat menjanjikan para tim sukses akan diberi sejumlah uang. Namun hanya pada sebelum hari pelaksanaan uang itu diberikan, dan uang tersebut dibagibagikan pada pemilih yang akan memilih kandidat yang didukung melalui pendataan." Lebih lanjut beliau mengatakan, "Setelah selesai pemilihan, gaji para tim sukses ada yang belum dibayarkan sampai saat ini. Meski begitu saya tetap memilihnya dalam pemilihan kepala daerah, meski figur kandidat tersebut kurang dikenal namun ini sudah menjadi satu komitmen." Dari jawaban yang diutarakan informan, menjelaskan bahwa ada yang dipertimbangkan Jemmy dalam memilih. Meskipun mengalami permasalahan saat mensukseskan salah satu kandidat, namun Jemmy menentukan sikapnya berdasarkan motivasi dan dorongan yang telah dibuat sedari awal. Hal ini menunjukkan tingginya sebuah komitmen dan kepercayaan antara pemilih dan kandidat. Hal berbeda pula diutarakan Vicky Wuisan (45 tahun, pekerjaan tidak tetap, tim sukses salah satu calon) mengatakan, "Saya adalah anggota salah satu partai namun tidak dilibatkan dalam pemilihan kepala daerah. Untuk itu saya membentuk tim yang terdiri dari rekanrekan serta teman-teman partai untuk mendukung salah satu kandidat lainnya." Selain mendukung calon lain, Vicky juga dijanjikan akan dibantu jika ia membutuhkan sesuatu. "Apabila menang dan jika ada hal yang dibutuhkan saya, akan dibantu oleh kandidat yang telah saya pilih." Hal ini memperlihatkan perilaku pemilih berdasarkan pilihan rasional. Yang mana, pemilih menentukan sikapnya berdasarkan alternatif-alternatif yang telah dipikirkan secara matang. Terlebih, alternatif yang dipilihnya untuk kepentingan diri sendiri. Berdasarkan hasil wawancara dengan para informan di atas 
menujukkan adanya kepentingan dalam memilih dan menerima uang yang diberikan oleh tim sukses.

\section{Kesimpulan}

Masyarakat pada dasarnya memiliki pemahaman yang cukup tinggi terhadap politik menyebabkan mereka memiliki kesadaran yang cukup tinggi pula untuk aktif berpartisipasi dalam pemilihan umum khususunya pemilihan kepala daerah Kota Jambi tahun lalu. Sejak ditetapkan UU No. 32 tahun 2004 tentang pemerintahan daerah, menyebabkan penyelenggaraan pemerintah ditentukan oleh daerah masingmasing. Oleh sebab itu, menuntut peran aktif warga Negara untuk berpatisipasi aktif dalam pengembangan daerah masingmasing dan salah satu contoh pengembangan daerah yaitu dengan memilih pemimpin yang akan memimpin daerahnya. Dalam hal ini pemilihan kepala daerah adalah salah satu contoh dalam penetapan undang-undang tersebut. Jadi pemilih adalah penentu daerah tersebut berkembang atau tidak, sama seperti kota Jambi sekarang. Perilaku pemilih pada mulanya berawal dari pengetahuan, pemahaman, perhatian pemilih terhadap masalah-masalah politik yang terjadi di masyarakat. Dan menjadi pembuat keputusan terpenting dan bertarung dalam kepentingan-kepentingan politik demi terwujudnya Negara yang demokrasi dan masyarakat sejahtera. Tingkat kepercayaan pemilih terhadap kandidat mempengaruhi pilihan mereka. Bagiamana hubungan emosional pemilih terhadap kandidat, bagaimana hubungan kedekatan pemilih terhadap kandidat yang akan mempengaruhi pilihan mereka. Perilaku pemilih di Kota Jambi pada pemilihan kepala daerah Kota Jambi dipengaruhi oleh beberapa faktor diantaranya yakni model sosiologis-psikologis, model identifikasi partai dan model rasionalitas. Ketiga faktor itulah yang paling berpengaruh diantara faktor-faktor yang telah ada sebelumnya.

\section{Saran}

Berdasarkan kesimpulan di atas, maka penulis mengemukakan beberapa saran, yaitu:

1. Penulis mengharapkan ke depannya partisipasi memilih masyarakat Kota Jambi akan meningkat lagi dan dibutuhkan kerjasama dengan semua pihak yang terlibat dalam kegiatan Pilkada ini.

2. Perlu diadakannya kajian tentang perilaku politik lebih mendalam dan perhatian pemerintah terhadap pemilih bukan hanya setelah 
kepentingan mereka terpenuhi kemudian pemilih ditinggalkan.

3. Perlu diadakannya pendidikan politik kepada semua warga Negara agar Indonesia terkhusus Kota Jambi secara menyeluruh memiliki pemilihpemilih yang cerdas dan buah produk dari pilihannya membawa Kota Jambi dan Indonesia menjadi lebih baik.

\section{Daftar Pustaka}

Bartels, Larry M. 2009. "The Study of Electoral Behavior" in Jan E. Leighley (ed), The Oxford Handbook of American Elections and Political Behavior. Oxford University Press, Oxford.

CSIS. Perilaku Pemilih Indonesia. Bahan Presentasi Publik. Jakarta 15 Juli 2008.

Davidson, Donald. 2004. Problems of Rationality. Oxford University Press: Oxford.

Dorussen, Han dan Michael Taylor (eds). 2002. Economic Voting. Routledge: London.

Evans, Jocelyn A J. 2004. Voter and Voting: An Introduction. Sage Publications. London, Thousand Oaks: New Delhi.
Ghaffar, Affan. 1992. Javanese Voters: A Case Study of Election Under Hegemonic Party System. Gadjah Mada University Press: Yogyakarta.

Heywood, Andrew. 2007. Politics. Third Edition. Palgrave Foundations: New York.

https://www.liputan6.com/pilkada/read/322 2167/pilkada-kota-jambi-2018-jadiajang pertarungan-2-petahana, diakses pada 6 Mei 2019.

Mery, Yanti and Alamsyah, Alamsyah (2014) Determinant of digital divide in Indonesia: the case of South Sumatera Province.Afro Asian Journal of Social Sciences, 5 (1). ISSN 2229-5313.

Liddle, Wiliam dan Saiful Mujani. "Leadership, Party, and Religion: Explaining Voting Behavior in Indonesia." Comparative Political Studies, Volume 40 Nomor 7, Juli 2015.

Liddle, Wiliam dan Saiful Mujani. "Indonesia: Personalities, Parties, and Voters." Journal of Democracy, Volume 21, Nomor 2, April 2016.

Surbakti, Ramlan. 2010. Memahami Ilmu Politik. PT Grasindo Umbara Citra, Jakarta.

Woshinsky, Oliver H. 2008. Explaining Politics: Culture, Institutions, and Political Behavior. Routledge. New York. 